\title{
THE RELATIONSHIP OF STREPTOLYSIN S INHIBITOR TO PHOSPHOLIPIDS IN THE SERUM OF HUMAN BEINGS AND EXPERIMENTAL ANIMALS
}

\author{
By GENE H. STOLLERMAN,1 BERNARD B. BRODIE, AND J. MURRAY STEELE \\ (From the Medical Services of the Maimonides Hospital of Brooklyn and the Department of \\ Medicine, State University of New York College of Medicine, Brooklyn; the Research \\ Service, New York University Division, Goldwater Memorial Hospital, New York \\ City; and the Section on Chemical Pharmacology, National Heart Institute, $\mathrm{Na-}$ \\ tional Institutes of Health, Public Health Service, Federal Security Agency, \\ Bethesda, Md.)
}

(Submitted for publication October 1, 1951; accepted November 5, 1951)

\section{INTRODUCTION}

The fall in the serum levels of streptolysin $\mathrm{S}$ inhibitor (SSI) which usually occurs during the acute phase of rheumatic fever $(1,2)$ suggested a disturbance of lipoprotein metabolism in this disease. Previous studies indicated that the inhibition of this streptococcal hemolysin by serum is associated with alpha and beta lipoproteins rather than with specific antibody (2-5). Streptolysin $S$ is inhibited by saline suspensions of phospholipids but not by cholesterol or neutral fats $(6,3)$. In addition, a large proportion of the SSI is destroyed by the action of $\mathrm{Cl}$. welchii lecithinase on serum (3). It therefore seemed possible that variation in SSI might reflect a parallel variation of serum lipoproteins rich in phospholipid.

The present study was undertaken to explore the relationship of serum levels of total phospholipid, lecithin and sphingomyelin to the SSI titer in the sera of patients with various diseases associated with disturbances in lipid metabolism, and in the sera of experimental animals with induced hyperlipemia. The observations reported below indicate that subnormal levels of SSI in the serum of human beings are associated with hypophospholipemia while elevation of SSI titer is encountered in diseases characterized by an increased concentration of serum phospholipids. The present study also indicates that an increase in SSI may be induced in animals rendered hyperlipemic by various methods.

\footnotetext{
1 Present address : Irvington House, Irvington-on-Hudson, N. $\mathbf{Y}$.
}

\section{MATERIALS AND METHODS}

Clinical material: Sera were obtained from 44 patients with diseases usually associated with either marked elevation or depression of serum phospholipids. The former group included 12 patients suffering from either intrahepatic or extrahepatic biliary obstruction (seven with biliary cirrhosis; three with serum hepatitis; one with a common duct calculus and one with carcinoma of the head of the pancreas); five patients manifesting the nephrotic syndrome; and three patients with hypothyroidism. The group of diseases associated with hypolipemia included seven patients with acute rheumatic fever; five with hyperthyroidism; three with fever of undetermined etiology; two with chronic lymphocytic leukemia; and one case of each of the following conditions: disseminated lupus erythematosus, scleroderma, subacute bacterial endocarditis, tuberculous pleurisy, carcinoma of the thyroid, ulcerative colitis and diffuse bronchiectasis.

Serial bleedings were obtained from several patients in an attempt to demonstrate a progressive rise or fall in phospholipid levels during the course of the disease.

Preservation of sera: Sera obtained from patients and from animals were stored at $-20^{\circ} \mathrm{C}$. Storage at $4^{\circ} \mathrm{C}$. was employed only in instances where titrations and chemical determinations were carried out within 48 hours after blood had been drawn. This precaution was taken because sera stored at $4^{\circ} \mathrm{C}$. for longer periods of time may show a progressive rise in SSI titer (3).

Titrations and chemical determinations: Titration of streptolysin $S$ inhibitor was performed by the method of Stollerman and Bernheimer (2). Lipid phosphorus was determined by the method of Fiske and SubbaRow (7) with minor modifications. Phospholipid levels are reported as milligrams of total phospholipid per $100 \mathrm{ml}$. and were calculated by multiplying the value for lipid phosphorus by 25 . Serum phospholipids were partitioned for the determination of lecithin and sphingomyelin by the method of Appleton and associates (8). Lecithin and sphingomyelin are expressed as milligrams per $100 \mathrm{ml}$. and were calculated by multiplying the choline chloride content of the respective fractions by the factor 5.7. Total and free cholesterol were determined by the method of Schoenheimer and Sperry (9). 
Methods for inducing hyperlipemia in rabbits and mice: An elevation of serum phospholipids in rabbits was produced by three different methods:

a) Six rabbits weighing between 1.5 and $2.5 \mathrm{~kg}$. were injected intravenously with the nonionic surface-active agent, Triton A-20 as described by Kellner, Correll, and Ladd (10). Commercial Triton A-20 is a $25 \%$ aqueous solution of Triton WR 1339, an alkyl aryl polyether alcohol.2 A $12.5 \%$ solution (Triton A-20 diluted with equal parts of isotonic saline) of this detergent was administered in doses of $1.25 \mathrm{ml}$. per $\mathrm{kg}$. three times weekly for nine weeks. The rabbits were maintained on a regular diet of Purina rabbit pellets.

b) Ligation of the common bile duct at its entrance into the duodenum was performed under nembutal anesthesia in six rabbits. The animals were bled at approximately weekly intervals thereafter during their survival.

c) Five rabbits were fed cholesterol over a period of two months. Cholesterol was dissolved in ether, mixed with Purina rabbit pellets and ether allowed to evaporate. Cholesterol was consumed at the rate of approximately $19 \mathrm{Gm}$. per rabbit per week and the animals gained weight steadily throughout the experiment.

Elevation of serum phospholipids in Swiss mice weighing 18-20 Gm. (CFW and Davis and Nagler strains) was induced by intraperitoneal injections of Triton A-20 diluted with equal parts of saline. One tenth $\mathrm{ml}$. was administered three times weekly during the first week and the dose increased to $0.2 \mathrm{ml}$. thrice weekly thereafter for four weeks. Groups of ten mice were bled from the heart at intervals during the experiment and serum samples of

2 Kindly supplied by Dr. Aaron Kellner and by Rohm \& Haas Co. each group were pooled for analysis of SSI, phospholipid and cholesterol levels. The mice were maintained on a diet of Purina Laboratory chow and gained weight steadily during the experiment.

\section{RESULTS}

\section{The relationship of phospholipid levels to SSI in the sera of patients with disturbance of lipid metabolism}

Fifty-eight sera obtained from 44 patients were analyzed for SSI and total phospholipid concentrations. Fifty of these sera were further analyzed for lecithin and sphingomyelin levels. The sera were grouped according to their SSI values. Table I shows the mean concentration and the range of values for serum phospholipids at varying levels of SSI.

In general, there appears to be a positive correlation between the concentration of serum phospholipids and the SSI titer. This relationship is best illustrated by the lecithin fraction. It can be noted, however, that the inhibition of streptoly$\sin \mathrm{S}$ by serum is not a simple function of lecithin concentration. At very low levels of serum lecithin the SSI titer falls abruptly while at high lecithin concentrations the rise in SSI tends to level off. It also appears that at normal levels of SSI

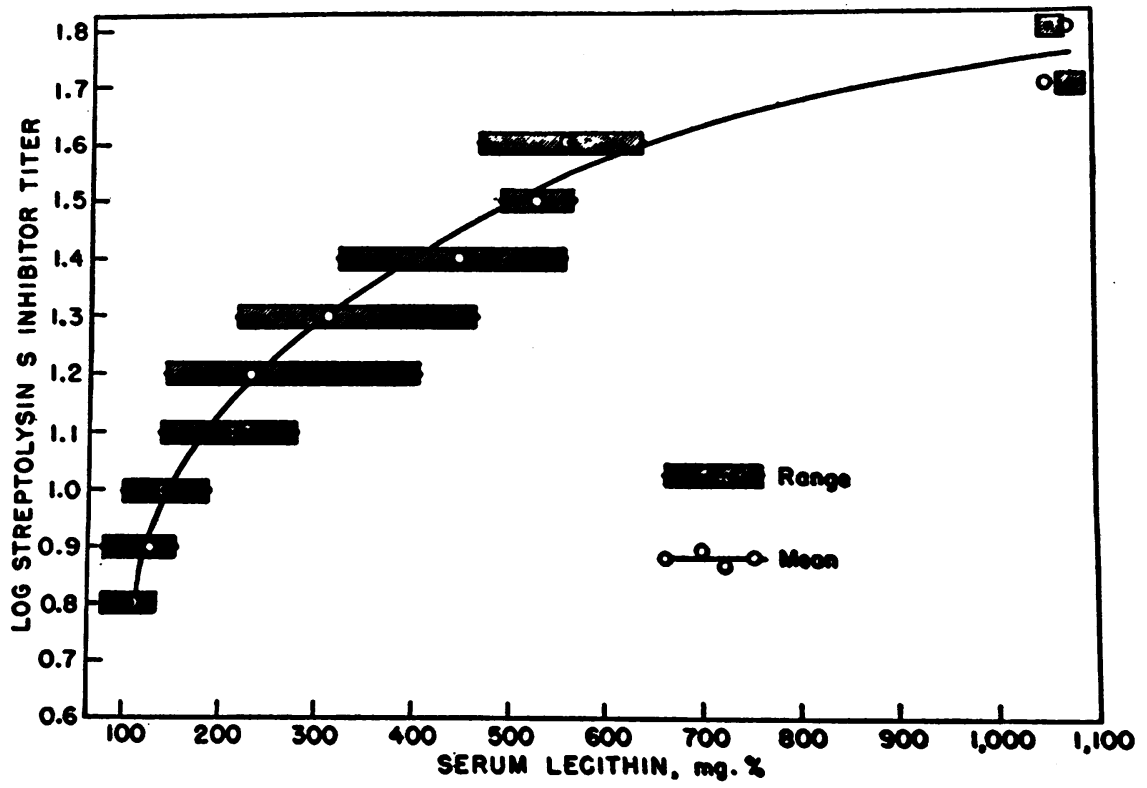

Fig. 1. Relationship of Lecithin Concentration to SSI in Human Sera Lecithin values in sera of the same SSI titer. 
TABLE I

Concentrations of total phospholipid, lecithin and sphingomyelin in human sera at various levels of streptolysin $S$ inhibition

\begin{tabular}{|c|c|c|c|c|c|c|c|c|c|}
\hline \multirow{2}{*}{$\underset{(u . / m l .)}{\text { SSI }}$} & \multicolumn{3}{|c|}{ Total phospholipid (mg.\%) } & \multicolumn{3}{|c|}{ Lecithin (mg.\%) } & \multicolumn{3}{|c|}{ Sphingomyelin (mg.\%) } \\
\hline & Mean & Range & No. of sera & Mean & Range & No. of sera & Mean & Range & No. of sera \\
\hline $\begin{array}{l}6.3 \\
8 \\
10 \\
12.5 \\
16.7 \\
20 \\
25 \\
33 \\
40 \\
50 \\
62.5\end{array}$ & $\begin{array}{r}176 \\
185 \\
201 \\
273 \\
261 \\
408 \\
585 \\
568 \\
663 \\
1,240 \\
1,275\end{array}$ & $\begin{array}{c}166-209 \\
127-209 \\
125-264 \\
179-365 \\
186-425 \\
302-618 \\
361-700 \\
510-625 \\
520-740 \\
- \\
-\end{array}$ & $\begin{array}{r}5 \\
7 \\
12 \\
12 \\
4 \\
4 \\
7 \\
2 \\
3 \\
1 \\
1\end{array}$ & $\begin{array}{r}111 \\
122 \\
140 \\
212 \\
228 \\
315 \\
447 \\
530 \\
558 \\
1,075 \\
1,057\end{array}$ & $\begin{array}{r}87-123 \\
77-154 \\
108-191 \\
138-278 \\
143-415 \\
221-466 \\
326-560 \\
490-570 \\
470-642 \\
- \\
-\end{array}$ & $\begin{array}{r}4 \\
7 \\
11 \\
10 \\
4 \\
3 \\
4 \\
3 \\
3 \\
1 \\
1\end{array}$ & $\begin{array}{l}17 \\
18.8 \\
25 \\
29.9 \\
27.2 \\
43.8 \\
43.1 \\
56.2 \\
55.4 \\
76.4 \\
92.3\end{array}$ & $\begin{array}{r}9.6-24.4 \\
9.1-29.6 \\
13.8-40.5 \\
13.7-47.2 \\
19.2-46.0 \\
21.3-80.0 \\
33.0-49.0 \\
55.4-57.0 \\
37.8-65.0 \\
- \\
-\end{array}$ & $\begin{array}{r}4 \\
7 \\
11 \\
10 \\
4 \\
3 \\
4 \\
2 \\
3 \\
1 \\
1\end{array}$ \\
\hline
\end{tabular}

there is a rather wide range of lecithin values (Figure 1).

The normal SSI titer in human serum varies between 10 and 20 units per $\mathrm{ml}$. with a mean value of 14.5 (2). Normal serum lecithin values by the method employed range between 128 and $219 \mathrm{mg}$. per $100 \mathrm{ml}$. Twenty-one of 22 sera with SSI values of 10 units or less contained lecithin in concentration below $160 \mathrm{mg}$. \%. The remaining sample of this group contained 10 units of SSI and $191 \mathrm{mg}$. \% of lecithin. All 14 sera with SSI values of 20 units or higher contained lecithin in concentrations greater than $219 \mathrm{mg}$. \%, the upper limit of normal.

The highest levels of SSI were found in two cases of biliary cirrhosis ( 50 and 62.5 units per $\mathrm{ml}$., respectively). These patients also showed the highest concentrations of lecithin encountered (1075 and $1057 \mathrm{mg}$. \%, respectively). Ten out of 12 patients with biliary obstruction had ele-



Fig. 2. Relationship of SSI and Phospholipid Levels in Serum during the Course of Acute Rheumatic Fever and Serum Hepatitis 
vated SSI titers and these were associated with serum lecithin values greater than $325 \mathrm{mg}$. per $100 \mathrm{ml}$. Only one patient with biliary obstruction and elevated serum phospholipids failed to manifest an abnormally high SSI. The remaining patient in this group with obstructive jaundice had a low SSI titer of 10 units per ml., and this was associated with a low serum lecithin value of $143 \mathrm{mg}$. per $100 \mathrm{ml}$. This patient had evidence of severe liver damage.

Of the group manifesting nephrotic syndrome, four out of five patients showed a rise in SSI cor- values below the normal and five of the eight had values of less than $128 \mathrm{mg}$. per $100 \mathrm{ml}$.

One patient with rheumatic fever and one with serum hepatitis afforded the opportunity to follow contrasting changes in serum lecithin by serial bleedings during the course of their respective diseases. The patient with rheumatic fever showed low serum lecithin levels during the acute stage of the disease which gradually rose to normal as rheumatic activity subsided. This was accompanied by a similar change in the SSI titer. The patient with serum hepatitis had a markedly ele-

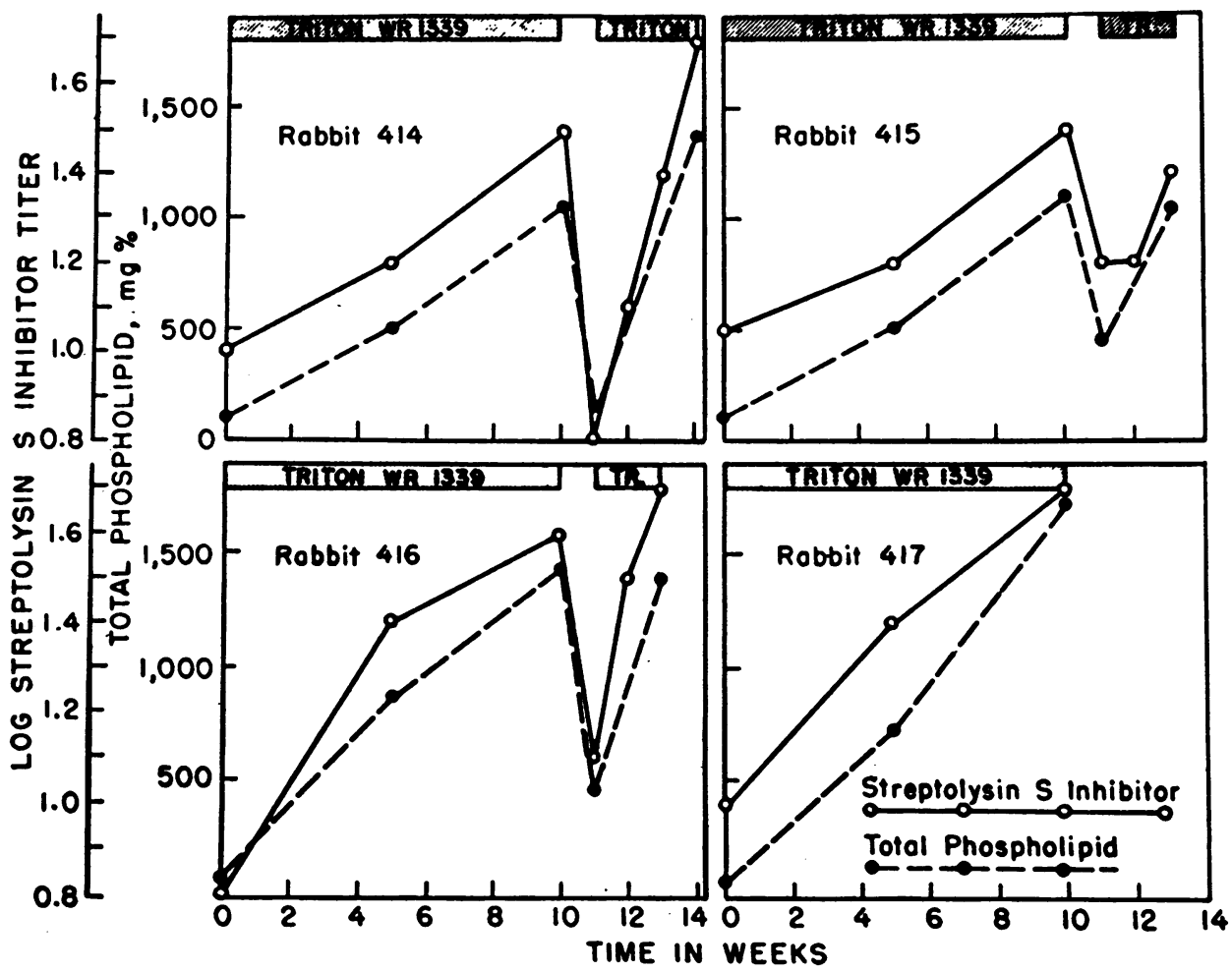

Fig. 3. Effects of the Intravenous Administration of Triton WR 1339 on the Concentrations of SSI and Total Phospholipid in Rabit Sera

responding with an abnormal elevation of serum lecithin.

Seven patients with severe acute rheumatic fever showed SSI values of 10 units or lower. All seven had concentrations of serum lecithin below $160 \mathrm{mg}$. per $100 \mathrm{ml}$. (the mean normal value) and in five of the seven the serum lecithin level fell below $128 \mathrm{mg}$. per $100 \mathrm{ml}$., the lower limit of normal. A group of eight patients suffering from miscellaneous diseases, in which SSI titers were also found to be low, all showed serum lecithin vated serum lecithin level during the acute stage of jaundice. As the disease subsided, lecithin levels returned to normal. This was accompanied by a parallel fall in SSI titer (Figure 2).

\section{The effects of induced hyperphospholipemia on} the level of SSI in the serum of rabbits

a) Following injections of Triton A-20: Repeated intravenous injections of Triton A-20 were followed by a rise of both SSI and total phospholipid in the serum of four rabbits. The rise 


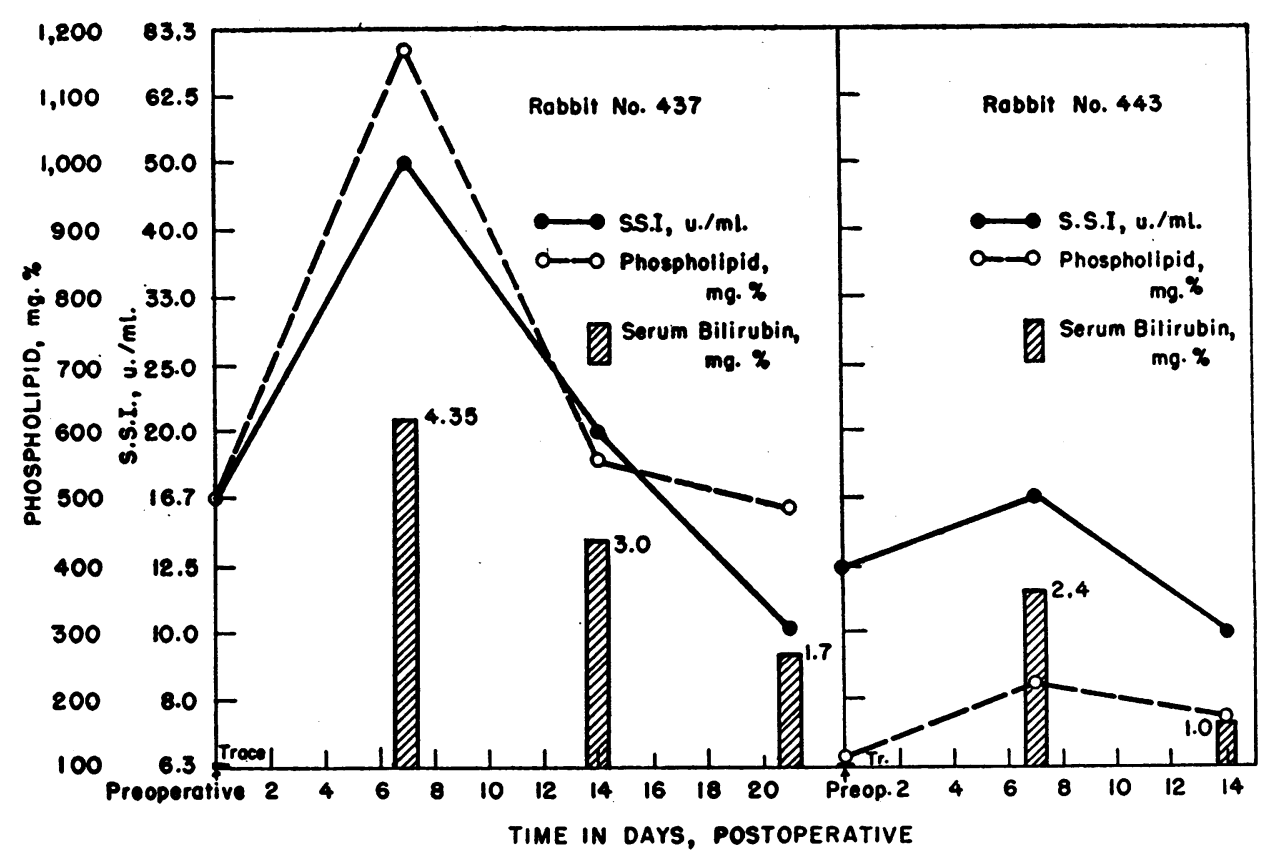

Fig. 4. Effect of Ligation of Common Bile Duct on the Levels of SSI and Phóspholipid in the Serum of Rabitts

in total phospholipid reached a peak after nine weeks (27 injections) in accordance with the phospholipid response previously described by Kellner, Correll, and Ladd (10). The level of SSI also rose progressively to a peak value of 50 units at the height of hyperlipemia. A significant rise in SSI was not apparent, however, until phospholipid values had increased to several times normal levels. When injections of Triton A-20 were discontinued, both total phospholipid and SSI levels returned to normal values and rose promptly again when injections were resumed (Figure 3).

Triton A-20 was itself found to inhibit streptolysin $\mathrm{S}$ in vitro. However, when the detergent was added to serum this inhibition was not apparent until concentrations of Triton A-20 exceeding $2 \%$ were reached. Although it is improbable that such concentrations of Triton A-20 were ever achieved in vivo with the dosage employed, other methods for the elevation of serum phospholipid were also employed to obviate this possible objection to the significance of the above data.

b) Following ligation of the common bile duct: The effect of ligation of the common bile duct on the concentrations of SSI and phospholipids of the serum of four rabbits was observed. Two of the rabbits developed marked hyperphospholipemia and this was associated with a comparable elevation of SSI. The remaining two animals developed only a mild rise in serum phospholipid and showed, correspondingly, but a slight increase in SSI (Figure 4).

c) Following cholesterol feeding: Feeding cholesterol to four rabbits was also followed by a rise in SSI and serum phospholipids (Table II). As with the above methods of inducing hyperphospholipemia, the titer of SSI followed variation in phospholipid concentration. Determination of free and total cholesterol was also performed on these sera since it has been observed that there is an increase in the ratio of serum cholesterol to phospholipid in rabbits fed cholesterol, while in rabbits receiving Triton A-20 this ratio may be reversed $(10,11)$. Despite the great increase in serum cholesterol observed in these rabbits, the SSI titer was no greater than that found in Triton A-20 treated rabbits at comparable concentrations of serum phospholipid. Therefore it appears that cholesterol levels have little direct influence on the concentration of SSI, an observation which was expected, since saline suspensions of cholesterol fail to inhibit streptolysin $\mathrm{S}$. 


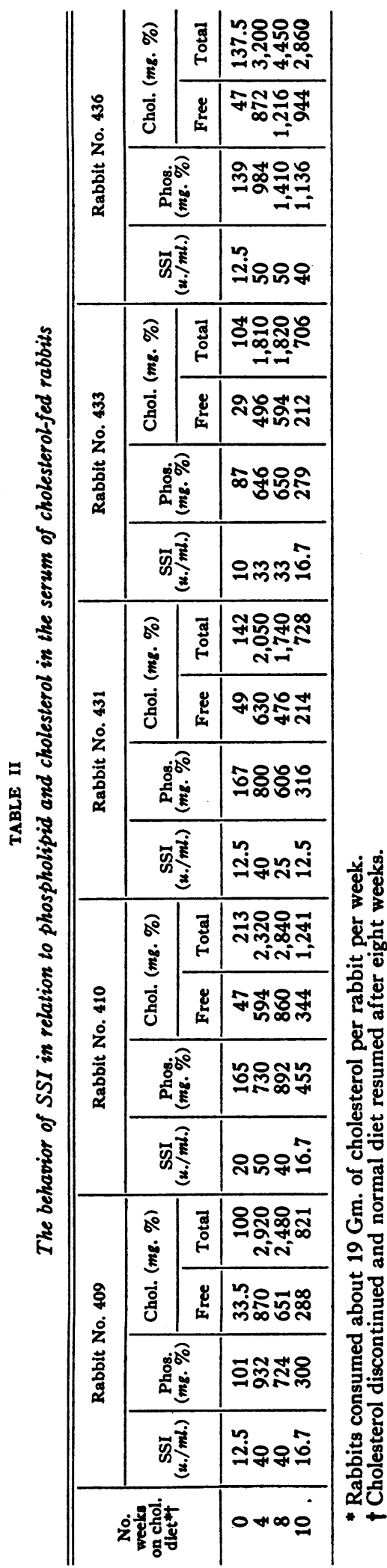

The effect of intraperitoneal injections on the concentrations of SSI and phospholipid in the serum of mice

A rise in serum phospholipid may be induced in mice, as well as in rabbits, by the administration of Triton A-20 and here, too, hyperphospholipemia is associated with a rise in SSI titer (Table III). The mouse sera, like rabbit sera, became intensely milky as the blood lipids rose. The mice appeared healthy and gained weight during the administration of the detergent.

TABLE III

SSI and phospholipid levels in the serum of mice following repeated intraperitoneal injections of Triton $A-20$

\begin{tabular}{c|c|c|c}
\hline \hline $\begin{array}{c}\text { No. of } \\
\text { injections* }\end{array}$ & Date bledt & SSI $(\boldsymbol{x} . / \mathrm{ml})$. & $\begin{array}{c}\text { Phospholipid } \\
(m \varepsilon . \%)\end{array}$ \\
\cline { 1 - 2 } & $1 / 4 / 51$ & 25 & 182 \\
15 & $2 / 7 / 51$ & 40 & 278 \\
25 & $3 / 2 / 51$ & 62.5 & 2,000 \\
\hline
\end{tabular}

* Triton A-20 injected as a $12 \frac{1}{2} \%$ solution of Triton WR 1339 in volumes of $0.2 \mathrm{ml}$. intraperitoneally three times weekly.

+ On the indicated dates 10 mice were sacrificed by bleeding from the heart, the blood samples pooled and determinations of SSI and phospholipid performed on the serum thus obtained.

\section{DISCUSSION}

It is apparent that variations in the titer of SSI reflect, in general, similar variations in serum phospholipid concentration. The subnormal levels of SSI encountered in rheumatic fever, and in certain other diseases, are indicative of hypophospholipemia. Conversely, elevations in SSI above normal levels have been found only in hyperphospholipemic sera.

A considerable range of phospholipid concentration may, however, occur at any given titer of SSI and at very high serum concentrations of phospholipid the increase in SSI tends to level off (Figure 1). This indicates that the inhibition of streptolysin $\mathrm{S}$ by serum is not a simple function of phospholipid concentration. Since the phospholipids of serum probably exist as components of lipoprotein molecules $(12,13)$, it is possible that the SSI titer is affected by variations in the physico-chemical composition of these proteins which occur in hyperlipemic states (13).

The significance of the fall in serum phospholipid which occurs in rheumatic fever is not un- 
derstood. The concentration of serum cholesterol has also been observed to fall during the acute phase of this disease (14), and to be lower in patients with rheumatic heart disease than in patients with hypertensive or arteriosclerotic heart disease (15). Both lipids decrease in concentration in the serum of patients with a variety of acute and chronic infectious diseases $(16,17)$. It has been suggested that the fall in the concentration of serum lipids is not a feature of a particular disease process but rather a non-specific metabolic disturbance common to debilitation and malnutrition (18). While this view appears reasonable, it has not yet been demonstrated that the hypolipemia of infectious diseases is induced by either hyperpyrexia or dietary deficiency alone (15).

The behavior of lipoproteins in hypolipemic states has not yet been adequately studied. Whether the newer methods for the separation and analysis of alpha and beta lipoproteins (12, 19,20 ) will reveal specific differences in the composition of these proteins during hypolipemia remains to be determined.

The non-antigenic properties of streptolysin $S$ have not heretofore provided the opportunity to study the pathogenicity of this toxin during streptococcal infections by classical antibody protection techniques. The induction of hyperlipemia in rabbits and mice affords a method of increasing SSI in these animals and thus potentially offers a unique opportunity to evaluate the role that a normal inhibitor may play as a host defense against a bacterial toxin. The increase in SSI titer is, however, clearly not of the magnitude usually encountered with the appearance of specific antibodies in serum. Studies are in progress to determine whether hyperlipemic animals develop increased resistance to the toxic effects of streptoly$\sin \mathrm{S}$ and to streptococcal infection.

\section{SUMMARY}

1. Variations in streptolysin $S$ inhibitor titer are associated with similar variations in the phospholipid content of human sera.

2. Elevated serum levels of SSI are found only in diseases associated with hyperphospholipemia. Conversely, a fall in SSI titer occurs in acute rheumatic fever and other diseases when serum phospholipids fall below normal levels.

3. The induction of hyperphospholipemia in rab- bits by repeated intravenous injections of the nonionic detergent, Triton A-20, by ligation of the common bile duct, and by feeding cholesterol results in an elevation of SSI titer. The SSI titer in mice may also be elevated by repeated intraperitoneal injections of Triton A-20.

\section{ACKNOWLEDGMENTS}

The able technical assistance of Fern Brook, Yetta Porosowska, and Betty Levy is gratefully acknowledged. The authors are also indebted to Dr. Colin M. MacLeod for his suggestions and advice during this study and to Dr. Alan W. Bernheimer who supplied streptolysin $\mathbf{S}$ for SSI titrations.

\section{REFERENCES}

1. Todd, E. W., Coburn, A. F., and Hill, A. B., Antistreptolysin $S$ titers in rheumatic fever. Lancet, 1939, 2, 1213.

2. Stollerman, G. H., and Bernheimer, A. W., The inhibition of streptolysin $\mathrm{S}$ by the serum of patients with rheumatic fever and acute streptococcal pharyngitis. J. Clin. Invest., 1950, 29, 1147.

3. Stollerman, G. H., Bernheimer, A. W., and MacLeod, C. M., The association of lipoproteins with the inhibition of streptolysin S by serum. J. Clin. Invest., 1950, 29, 1636.

4. Humphrey, J. H., The nature of antistreptolysin "S" in the sera of man and of other species: antistreptolysin titres in normal and diseased states. Brit. J. Exper. Path., 1949, 30, 345.

5. Humphrey, J. H., The nature of antistreptolysin $S$ in the sera of man and of other species. The lipoprotein properties of antistreptolysin S. Brit. J. Exper. Path., 1949, 30, 365.

6. Hewitt, L. F., and Todd, E. W., The effect of cholesterol and of sera contaminated with bacteria on the hemolysins produced by hemolytic streptococci. J. Path. \& Bact., 1939, 49, 45.

7. Fiske, C. H., and SubbaRow, Y., The colorimetric determination of phosphorus. J. Biol. Chem., 1925, 66,375 .

8. Appleton, H. D., Levy, B. B., Steele, J. M., and Brodie, B. B., Procedure for the chemical estimation of free choline in plasma. Federation Proc., $1950,9,146$.

9. Schoenheimer, R., and Sperry, W. M., A micromethod for the determination of free and combined cholesterol. J. Biol. Chem., 1934, 106, 745.

10. Kellner, A., Correll, J. W., and Ladd, A. T., Sustained hyperlipemia induced in rabbits by means of intravenously injected surface-active agents. J. Exper. Med., 1951, 93, 373.

11. Kellner, A., Correll, J. W., and Ladd, A. T., The influence of intravenously administered surface-active agents on the development of experimental atherosclerosis in rabbits. J. Exper. Med., 1951, 93, 385. 
12. Oncley, J. L., Gurd, F. R. N., and Melin, M., Preparation and properties of serum and plasma proteins. $\mathrm{XXV}$. Composition and properties of human serum beta-lipoprotein. J. Am. Chem. Soc., 1950, $72,458$.

13. Gofman, J. W., Jones, H. B., Lindgren, F. T., Lyon, T. P., Elliott, H. A., and Strisower, B., Blood lipids and human atherosclerosis. Circulation, 1950, $2,161$.

14. Offenkrantz, F. M., Serum cholesterol in patients with rheumatic fever; further study. Am. J. Dis. Child., 1938, 56, 67.

15. Poindexter, C. A., and Bruger, M., Cholesterol content of the blood in heart disease. Arch. Int. Med., 1938, 61, 714.

16. Stoesser, A. V., and McQuarrie, I., Influence of acute infection and artificial fever on the plasma lipids. Am. J. Dis. Child., 1935, 49, 658.
17. King, S. E., and Bruger, M., Plasma cholesterol in tuberculosis and amyloid disease. Ann. Int. Med., 1935, 8, 1427.

18. Peters, J. P., and Van Slyke, D. D., Quantitative Clinical Chemistry. Interpretations. Williams \& Wilkins Co., Baltimore, Md., 1946, Vol. I, p. 537.

19. Cohn, E. J., Gurd, F. R. N., Surgenor, D. M., Barnes, B. A., Brown, R. K., Derouaux, G., Gillespie, J. M., Kahnt, F. W., Lever, W. F., Liu, C. H., Mittelman, D., Mouton, R. F., Schmid, K., and Uroma, E., A system for the separation of the components of human blood: Quantitative procedures for the separation of the protein components of human plasma. J. Am. Chem. Soc., 1950, 72, 465.

20. Gofman, J. W., Lindgren, F. T., and Elliott, H., U1tracentrifugal studies of lipoproteins of human serum. J. Biol. Chem., 1949, 179, 973. 